\title{
Zorgen om de zorg : hoe de kwaliteit van de verpleging de kwaliteit van zorg bepaalt
}

Citation for published version (APA):

de Wit, A. (2007). Zorgen om de zorg : hoe de kwaliteit van de verpleging de kwaliteit van zorg bepaalt. Maastricht University. https://doi.org/10.26481/spe.20071123rw

Document status and date:

Published: $23 / 11 / 2007$

DOI:

10.26481/spe.20071123rw

Document Version:

Publisher's PDF, also known as Version of record

\section{Please check the document version of this publication:}

- A submitted manuscript is the version of the article upon submission and before peer-review. There can be important differences between the submitted version and the official published version of record.

People interested in the research are advised to contact the author for the final version of the publication, or visit the DOI to the publisher's website.

- The final author version and the galley proof are versions of the publication after peer review.

- The final published version features the final layout of the paper including the volume, issue and page numbers.

Link to publication

\footnotetext{
General rights rights.

- You may freely distribute the URL identifying the publication in the public portal. please follow below link for the End User Agreement:

www.umlib.nl/taverne-license

Take down policy

If you believe that this document breaches copyright please contact us at:

repository@maastrichtuniversity.nl

providing details and we will investigate your claim.
}

Copyright and moral rights for the publications made accessible in the public portal are retained by the authors and/or other copyright owners and it is a condition of accessing publications that users recognise and abide by the legal requirements associated with these

- Users may download and print one copy of any publication from the public portal for the purpose of private study or research.

- You may not further distribute the material or use it for any profit-making activity or commercial gain

If the publication is distributed under the terms of Article $25 \mathrm{fa}$ of the Dutch Copyright Act, indicated by the "Taverne" license above, 


\section{Zorgen om de zorg:}

Hoe de kwaliteit van de verpleging de kwaliteit van zorg bepaalt

\section{Rede}

uitgesproken bij de aanvaarding van het ambt van

hoogleraar in de Verplegingswetenschap

i.h.b. de verpleegkundige aspecten van zorgprocessen

aan de Universiteit Maastricht

op vrijdag 23 november 2007

door

Prof. Dr. Rianne de Wit 
Inhoudsopgave

Prof. Dr. Rianne de Wit, Universiteit Maastricht

1. Inleiding 3

2. De verpleging 4

3. Kwaliteit van zorg 6

4. Onderzoek 9

5. Toekomstig onderzoek 15

6. Onderwijs 18

$\begin{array}{ll}\text { 7. Tot slot } & 19\end{array}$

8. Dankwoord 19

9. Referenties 22 
Oratie

\section{Inleiding}

Mijnheer de Rector Magnificus, geacht College van Bestuur, gewaardeerde collega hoogleraren, collega's, medewerkers van het azM, verpleegkundigen en verzorgenden, familie en vrienden en alle andere aanwezigen. Ik beschouw het als een eer en een groot voorrecht dat ik mijn inaugurele rede voor $u$ allen mag uitspreken.

Stel u bent bijna 80 jaar en als gevolg van artrose (gewrichtsslijtage) heeft $u$ moeite met lopen, het gewricht doet pijn en de belastbaarheid neemt af. Dat is niet denkbeeldig, want jaarlijks hebben 20.000 mensen hier mee te maken, zo ook mijn vader. U krijgt een totale heupoperatie. Tijdens de operatie wordt het aangetaste gewricht vervangen door een kunstgewricht. Het herstel van dit kapsel heeft tijd nodig. Daarom krijgt u na de operatie leefregels om te voorkomen dat de heup uit de kom schiet. U krijgt antibiotica toegediend om de kans op een infectie te verkleinen. Na de ingreep gaat u naar de recovery (uitslaapkamer). Wanneer uw toestand stabiel is, komt de verpleegkundige u ophalen en brengt u weer terug naar de afdeling, informeert het thuisfront, ziet toe op de drains (slangetjes) in de wond, die zorgen voor de afvoer van bloed en wondvocht en zorgt voor adequate pijnbestrijding en ontstekingsremmers.

Diverse keren controleert de verpleegkundige u, overdag en 's nachts en constateert diverse bloedingen. Extra bloedtoevoer volgt. $U$ verblijft ruim 5 dagen in het ziekenhuis en het verdere herstel neemt zo'n 6 weken in beslag. Maar stel nu dat het 1985 is, in plaats van 2007, dus ruim 20 jaar eerder. Dan had $u$ niet alleen ongeveer 4 weken in het ziekenhuis gelegen, naar alle waarschijnlijkheid had u op deze leeftijd geen heupprothese gekregen. Niet alleen de enorme evolutie in de heupprothesechirurgie heeft tot een betere behandeling geleid, door middel van een multi-modale interventie, bestaande uit pijnbestrijding, voldoende vochtbalans, behandeling van eventuele 
bloedarmoede en postoperatieve mobilisatie, verblijt u slechts 5 dagen in het ziekenhuis. In plaats van de welbekende bedrust wordt u kort na de operatie gemobiliseerd. Die mobilisatie is van belang om spieratrofie te voorkomen (Siu et al., 2006). Immers, zelfs bij een gezond mens neemt de spierkracht na een week bedrust $10-15 \%$ af, en na acht weken volledige immobilisatie bedraagt de spierkracht nog ongeveer $40 \%$ van de waarde voorafgaande aan de immobilisatieperiode (Bloomfield, 1997; Gogia et al., 1988). Daarnaast bestaat een risico op het ontwikkelen van een infectie en doorligwonden (decubitus). De verpleegkundige vervult een belangrijke taak bij het geven van zorg om ervoor te zorgen dat de gezondheid zich weer herstelt. En het is die zorg waar ik in deze oratie aandacht aan wil besteden: zorgen om de zorg.

\section{De verpleging}

Zorg wordt door verpleegkundigen en verzorgenden verricht. In Nederland zijn meer dan 424.000 verpleegkundigen en verzorgenden werkzaam (LEVV, 2006a; 2006b). Daarmee vormen verpleegkundigen en verzorgenden de grootste beroepsgroep binnen de gezondheidszorg. De verpleegkundige beroepsgroep kent verpleegkundigen met een basisopleiding (MBO of $\mathrm{HBO}$ ); verpleegkundigen met een vervolgopleiding (gespecialiseerd verpleegkundigen zoals de oncologieverpleegkundige) en de Nurse Practitioners (NP), verpleegkundigen die na een vierjarige HBO-V-opleiding en een aantal jaren praktijkervaring een tweejarige HBO-Mastersopleiding hebben gevolgd. Verpleegkundigen maken ruim de helft van de totale groep uit die werkzaam is in de zorg (233.412; 55\%). Wat houdt het werk van een verpleegkundige in? De verpleegkundige houdt zich met name met vier belangrijke taken bezig (ICN, 2006):

(1) het bevorderen van gezondheid;

(2) het voorkomen van ziekten;

(3) het herstellen van gezondheid; en

(4) het verlichten van het lijden. 
Dat betekent dat verpleegkundigen een bijdrage leveren aan: (1) het toepassen van preventie door het geven van voorlichting, advies en instructie (zoals leefstijladviezen bij chronische aandoeningen); (2) het verlenen van ondersteuning bij de persoonlijke basiszorg (zoals hygiëne en voeding); (3) het verrichten van verpleegtechnische handelingen (zoals wondverzorging en pijnbestrijding); (4) het verlenen van ondersteuning bij het voeren van de regie over het eigen leven (zelfmanagement) (zoals patiënten leren injecteren en apparatuur leren gebruiken); en (5) het geven van psychosociale begeleiding (van de Haterd et al., 2005).

In hoeverre onderscheidt verpleegkundige zorg zich van medische behandeling? Vaak wordt dan het onderscheid gemaakt tussen "cure" (herstel van ziekte) en "care" (verpleging en verzorging), waarbij de medische behandeling zich richt op de oorzaken en behandeling van de ziekte/aandoening, terwijl de verpleging en verzorging zich meer richt op de gevolgen van de ziekte/aandoening.

Maar in toenemende mate groeien verpleegkunde en geneeskunde naar elkaar toe. Verpleegkundigen en artsen gaan steeds meer multidisciplinair werken. Bovendien is er een continue verschuiving gaande waarbij verpleegkundigen handelingen verrichten die in het verleden door artsen werden uitgevoerd, of nieuwe handelingen uitvoeren die voorheen nog niet bestonden. Dat varieert van het geven van voorlichting aan patiënten, tot het coördineren van de pre-, perien postoperatieve zorg, tot de recente ontwikkeling waarbij gespecialiseerd verpleegkundigen zelfstandig geneesmiddelen voorschrijven aan gediagnosticeerde patiënten.

Is er dan nog wel sprake van een duidelijk onderscheid tussen medische behandeling en verpleegkundige zorg? Er zijn duidelijk verschillen, maar er is ook overlap. Voor de patiënt maakt het niet uit, hij wil goed worden behandeld, zowel door een arts als een verpleegkundige. Het gaat om goed geïntegreerde zorg, waarbij medische behandeling en verpleegkundige zorg op elkaar zijn afgestemd. De verpleegkundige onderscheidt zich vooral door haar continue aanwezigheid bij de patiënt. De verpleegkundige ziet de patiënt 24 uur per dag en is het belangrijkste aanspreekpunt in de zorg. Artsen en andere disciplines 
komen veelal niet vaker dan een keer per dag bij de patiënt. De verpleegkundige is niet alleen de ogen, oren, handen en voeten voor de patiënt, maar ook voor de dokter. De verpleegkundige ziet erop toe dat zorgproblemen worden gesignaleerd en behandeld en dat de patiënt in een veilige omgeving verblijft. Het verrichten van adequate zorg vereist verpleegkundige kennis en vaardigheden die gebaseerd dienen te zijn op onderzoek of te zijn gebaseerd op enig bewijs van onderzoek. Door middel van verplegingswetenschappelijk onderzoek wordt een bijdrage geleverd aan de wetenschappelijke ontwikkeling en onderbouwing van de verpleegkundige zorgverlening. Op die manier helpen wetenschappers hun beroepsgroep verder naar een hoger niveau van professionalisering (Stevens en Philipsen, 2003).

\section{Kwaliteit van zorg}

Hoe is het gesteld met de kwaliteit van de verpleegkundige zorg? Om deze vraag te beantwoorden is het nodig om de bijdrage van verpleegkundigen van de totale zorg te onderscheiden. Immers, de kwaliteit van zorg is een optelsom van zorg die door alle hulpverleners wordt verleend, afgestemd op de vraag van de patiënt. Dat brengt mij bij het eerste punt van zorg. De kwaliteit van de verpleegkundige zorg staat onder druk. Ik wil dit illustreren aan de hand van een beschrijving van een oncologische verpleegafdeling in het academisch ziekenhuis Maastricht (azM). Deze verpleegafdeling van het azM bestaat uit 36 bedden. Op de eerste unit, liggen 19 patiënten met leukemie, patiënten die een transplantatie ondergaan en oncologische patiënten met complicaties als gevolg van chemotherapie. Veel voorkomende complicaties zijn: koorts, mucositis, ernstige huidafwijkingen ten gevolge van de chemotherapie, ernstige diarree, hemodynamische instabiliteit en respiratoire problemen. De patiënten hebben nagenoeg allemaal een infuus. Patiënten krijgen verschillende chemotherapiekuren in verschillende schema's toegediend. Reacties en klachten bij patiënten worden nauwlettend geobserveerd en volgens protocol behandeld. Infecties zijn veelvoorkomend, waardoor patiënten bacteriearme voeding krijgen 
om infecties door middel van voeding te voorkomen. Hygiëne is niet alleen voor de patiënt belangrijk, maar ook voor de verpleegkundige. Naast verpleegtechnische handelingen maakt psychosociale begeleiding een wezenlijk deel uit van de zorg. De tweede unit bestaat uit een gevarieerde unit met 12 patiënten met Maag-Darm-Leverziekten en vijf patiënten met psychiatrische problematiek.

In de dagdienst werken op de eerste unit vijf tot zes gediplomeerde verpleegkundigen en twee stagiaires of leerling-verpleegkundigen. Op de tweede unit werken drie verpleegkundigen en een stagiaire of leerling-verpleegkundige. In de avonddienst daalt dit aantal naar vier verpleegkundigen op de eerste unit en drie verpleegkundigen op de tweede unit. 's Nachts wordt het personeel gecombineerd en zijn drie gediplomeerd verpleegkundigen beschikbaar die zorg dragen voor het totaal van 39 patiënten.

Op deze afdeling is de groep patiënten die zware en intensieve zorg nodig heeft gestegen in de afgelopen jaren. Omdat de bedbezetting al jaren hoog is, blijft het aantal verpleegdagen nagenoeg stabiel. Maar tegelijkertijd is het aantal verpleegkundigen in de afgelopen jaren gedaald. Dit heeft tot gevolg dat de werklast zo'n 5\% per jaar is gestegen gedurende meerdere jaren.

Deze verpleegafdeling staat niet op zichzelf. $\mathrm{Na}$ een soortgelijke ontwikkeling in de verpleeg- en verzorgingssector, de thuiszorg en de gehandicaptenzorg, getuige de ruime berichtgeving hierover in de media, staat de ziekenhuiszorg onder druk. Verpleegkundigen ervaren dit zelf. Uit een recent panelonderzoek blijkt dat een kwart van de verpleegkundigen en verzorgenden vindt dat er te weinig personeel en/of onvoldoende gekwalificeerd personeel is om de veiligheid van hun cliënten te waarborgen (de Veer et al., 2007). Maar is dat nu een subjectieve beleving die past bij de hedendaagse "wij zijn zo druk" cultuur? Het antwoord daarop is nee. Deze trend is niet alleen in dit ziekenhuis maar ook in andere ziekenhuizen waar te nemen (Prismant, 2007). Het aantal verpleegkundigen dat werkzaam is in de Nederlandse ziekenhuizen is in de afgelopen jaren gedaald. Ook het aantal leerling-verpleegkundigen is gedaald. Het aantal verpleegdagen is sterk gestegen, evenals het aantal patiënten dat 
complexe zorg nodig heeft. Maar de reductie van het aantal verpleegkundigen is van invloed op de kwaliteit van zorg.

Onderzoek laat zien dat er een relatie bestaat tussen het aantal verpleegkundigen per patiënt en de kwaliteit van zorg. Amerikaans onderzoek laat zien dat het wenselijke aantal patiënten per verpleegkundige vier is. Stijgt het aantal patiënten van vier naar zes patiënten per verpleegkundige, dan daalt de patiëntveiligheid. Dit heeft een stijging van het aantal patiënten met een urineweginfectie, longontsteking, gastero-intestinale bloedingen en shock tot gevolg waardoor de mortaliteit met $14 \%$ stijgt. Wanneer het aantal patiënten per verpleegkundige verder stijgt naar acht patiënten per verpleegkundige, dan stijgt de mortaliteit met 31\% (Aiken et al., 2002a; 2002b). Recent Engels onderzoek bevestigt dit resultaat (Estabrooks et al., 2005; Needleman et al., 2002; Rafferty et al., 2007). Ziekenhuizen met de hoogste patiënt-verpleegkundige ratio hadden een $26 \%$ hogere mortaliteit vergeleken met ziekenhuizen met de laagste patiëntverpleegkundige ratio. Niet alleen de hoeveelheid verpleegkundigen bepaalt de kwaliteit van zorg, ook het opleidingsniveau van verpleegkundigen draagt hieraan bij. Door de inzet van hoger opgeleide verpleegkundigen neemt de sterftekans af in vergelijking met de inzet van lager opgeleide verpleegkundigen (Aiken et al., 2003; Clarke et al., 2002).

Daarmee wil ik mijn tweede punt van zorg aangeven: bezuinigen op het aantal en de kwaliteit van de verpleegkundigen is onverstandig, zolang deze niet gepaard gaat met een meer efficiënte wijze van werken. Daalt het aantal verpleegkundigen bij een stijgende zorgvraag, dan daalt de patiëntveiligheid, met zelfs een stijging van de mortaliteit tot gevolg.

Maar de grootste beroepsgroep in de gezondheidszorg, die de meest prominente rol inneemt waar de zorg plaatsvindt, heeft veelal geen grote beslissingsbevoegdheid. De tijd dat de verpleging werd vertegenwoordigd door middel van een verpleegkundig directeur op het niveau van de directie of Raad van Bestuur ligt al ruime tijd achter ons. Dit geldt zowel voor de directie en Raden van Bestuur als voor het hoger management. Op dit moment is de verpleging slechts in enkele Raden van Bestuur van ziekenhuizen $(\mathrm{N}=4)$ 
vertegenwoordigd. Om de patiënt daadwerkelijk centraal te stellen, is het van belang dat een vertegenwoordiger van de verpleging wordt opgenomen die kan meebeslissen over het beleid, alsmede om oplossingen voor de tekorten aan de vraag- en aanbodzijde te realiseren. Ik pleit dan ook voor het herinvoeren van de verpleegkundige directeur en het uitbreiden van het aantal managers met een verpleegkundige opleiding.

Deze ontwikkeling is zeer wenselijk naast andere ontwikkelingen die leiden tot het verder professionaliseren van de verpleging. Naast de landelijke invloed van organisaties als de beroepsvereniging van Verpleegkundigen \& Verzorgenden Nederland (V\&VN) en het Landelijk Expertisecentrum Verpleging en Verzorging (LEVV), draagt ook de ontwikkeling van de Verpleegkundige- en/of Verzorgende Adviesraad (VAR) (V\&VN, 2007) hieraan bij. Het is hun taak om problemen van verpleegkundigen op de werkvloer onder de aandacht te brengen.

\section{Onderzoek}

Hierbij ben ik aangekomen bij een van mijn hoofdtaken en daar waar mijn grootste passie ligt: onderzoek. Om de kwaliteit van de zorgverlening op peil te houden, te verbeteren en de slag te maken naar meer doelmatige zorg, is het van belang dat verplegingswetenschappelijk onderzoek wordt uitgevoerd.

Verplegingswetenschappelijk onderzoek richt zich op het beschrijven van verpleeg- en zorgproblemen en de gevolgen daarvan voor de patiënt, evenals het ontwikkelen en toetsen van effectieve interventies en modellen van zorgverlening.

Daarbij ben ik bij mijn derde punt van zorg aangekomen. In Nederland bestaan drie vakgroepen met bijbehorende hoogleraren die onderzoek verrichten naar zorgprocessen binnen de verpleging. De vakgroep Verpleging en Verzorging van de Universiteit Maastricht is daar een voorbeeld van. Het aantal gepromoveerde verpleegkundigen in Nederland bedraagt ongeveer 70 . Dat is $0.02 \%$ van het totaal aantal verpleegkundigen en verzorgenden. In de Verenigde Staten is 0,6\% gepromoveerd (American Association of Colleges of Nursing, 2005) en in 
Canada streeft men naar 0.4\% gepromoveerden in 2014 (Canadian Association of Schools of Nursing, 2004; Wood et al., 2004).

leder vergelijk met een andere discipline, zoals geneeskunde, gaat mank. Het totale aantal gepromoveerde verpleegkundigen is alleen al kleiner dan het aantal dat jaarlijks binnen 2 faculteiten Geneeskunde promoveert (Stukart et al., 2006). Tot voor kort baseerden verpleegkundigen hun handelen op hun eigen praktijkervaring en wat zij in de opleiding hadden geleerd. Niet tradities en rituelen, maar wetenschappelijke principes vormen de basis voor beslissingen bij het uitvoeren en evalueren van verplegen. Een sterkere groei van het aantal wetenschappers dat onderzoek binnen de verpleging uitvoert is noodzakelijk, evenals het aantal vakgroepen.

Het huidige onderzoek van de vakgroep Verpleging en Verzorging is ingebed in de 'School for Public Health and Primary Care' van het Care en Public Health Research Institute (CAPHRI) en betreft twee onderzoeksprogramma's, te weten: (1) zorg voor chronische zieken en (2) zorg voor de oudere patiënt. Het doel van dit onderzoek is het bijdragen aan kennis dat van nut is voor de verpleegkundige praktijk, om de kwaliteit van zorg te verbeteren.

Mijn onderzoek heeft zich altijd gericht op het verlichten van symptomen, als pijn, misselijkheid, vermoeidheid, etc. Het uitgangspunt daarbij is dat de kwaliteit van zorg verbetert door het verpleegkundig handelen te verbeteren. In 1990 begon in het Nederlands Kanker Instituut / Antoni van Leeuwenhoek ziekenhuis mijn fascinatie voor pijn. Daar had ik twee redenen voor:

(1) Omdat pijn de meest voorkomende klacht is en grote invloed heeft op je gehele doen en laten. Pijn is daarmee van grote invloed op de kwaliteit van leven; (2) Indertijd was de gedachte dat verpleegkundigen een belangrijke taak hebben bij de pijnbestrijding nog geen gemeengoed. In de daaropvolgende jaren heb ik diverse onderzoeken naar pijn uitgevoerd, onder andere vanuit mijn functie als hoofd van het Pijnkenniscentrum in het Erasmus MC in Rotterdam. Het primaire doel van de Pijnkenniscentra, verbonden aan de academische ziekenhuizen van Maastricht, Rotterdam, Nijmegen en Groningen is het ontwikkelen van kennis over pijn en pijnbestrijding en deze kennis breed 
verspreiden onder alle professionals in de gezondheidszorg ten einde de best mogelijke behandeling en verzorging voor patiënten met pijn te realiseren.

De eerste en meest belangrijke stap bij goede pijnbestrijding is het signaleren en meten van pijn. Meten is weten. Zonder het meten van de ernst van de pijn kan geen adequate behandeling en verzorging van pijn plaatsvinden. En daarbij hebben verpleegkundigen een belangrijke taak. Nagenoeg alle chirurgische ingrepen gaan gepaard met pijn. Afhankelijk van de grootte en plaats kunnen wonden na de operatie veel pijn geven. Een hogere pijnintensiteit leidt tot meer pulmonale en cardiale problemen in de postoperatieve periode, verminderde kwaliteit van leven en een langere opnameduur (Kehlet et al., 2004; Watt-Watson et al., 2001). Niet alleen verloopt het postoperatieve herstel trager met minder tevreden patiënten, tevens kan niet goed behandelde acute pijn leiden tot chronische pijn (Karanikolas et al., 2000; Kehlet, 1999). Onderzoek heeft aangetoond dat het dagelijks meten van postoperatieve pijn bijdraagt aan een betere pijnbestrijding. Dit kan op eenvoudige wijze plaatsvinden, door tijdens de controles van bloeddruk, pols en temperatuur ook pijn te meten. De verpleegkundige vraagt aan de patiënt een cijfer te geven voor de pijnintensiteit, waarbij 0 geen pijn is en 10 de ergst denkbare pijn. De pijncijfers worden in grafiekvorm uitgezet op de temperatuurlijst. Hierdoor ontstaat een curve en is in één oogopslag te zien in welke mate een patiënt pijn heeft en hoe effectief de pijnbestrijding is. Het dagelijks meten van pijn leidt tot meer inzicht bij verpleegkundigen en het sneller en beter toepassen van de pijnbestrijding, waardoor patiënten minder pijn ervaren. Onderzoeken laten zien dat het haalbaar is om dagelijks systematische pijnmetingen uit te voeren in de verpleegkundige praktijk en dat deze effectief zijn (De Rond et al., 1999; 2001). Sinds 2003 dienen ziekenhuizen hun prestaties op het gebied van patiëntveiligheid en effectiviteit te presenteren aan de hand van prestatieindicatoren. Prestatie-indicatoren zijn meetbare aspecten van de zorg die een aanwijzing geven over bijvoorbeeld de kwaliteit, de veiligheid, de doelmatigheid en de toegankelijkheid van de zorg. Het uitvoeren van postoperatieve 
pijnregistraties in Nederlandse ziekenhuizen is als prestatie-indicator aangemerkt (Inspectie voor de Gezondheidszorg, 2006).

Uit de gegevens van de Inspectie voor de Gezondheidszorg (IGZ, 2006a; 2006b; 2007) blijkt dat het aantal ziekenhuizen dat bij alle postoperatieve patiënten pijnmetingen verricht sinds 2004 is toegenomen van 30\% naar 50\%; het aantal ziekenhuizen dat bij een deel van de postoperatieve patiënten pijnmetingen verricht is gestegen van $10 \%$ naar $27 \%$. Maar het percentage ziekenhuizen waar patiënten binnen 72 uur na de operatie een acceptabele pijnscore behalen is gedurende de afgelopen jaren constant gebleven. $\mathrm{Er}$ is inmiddels een hele wereld gewonnen, maar er is ook nog een lange weg te gaan.

En dat brengt mij op het vierde punt van zorg. Het landelijk implementeren van innovaties in de zorg verreist een enorme inspanning en hiervoor is de verpleegkundige organisatie onvoldoende toegerust. Deskundigheidsbevordering, attitudeverandering en het ondersteunen van implementatieprocessen zijn hiervoor noodzakelijk. Verpleegkundigen dienen meer tijd te krijgen om deze kennis eigen te maken en toe te passen in de praktijk. Structurele scholing gedurende het gehele leven is daarbij van wezenlijk belang. Onderzoek laat zien dat de weg die wordt afgelegd van wetenschappelijk onderzoek naar het invoeren van een innovatie in ten minste 50\% van de instellingen zo'n 17 jaar duurt (Balas en Boren, 2000). In het voorbeeld van het systematisch invoeren van pijnregistratie in ziekenhuizen en andere instellingen blijkt dit op het jaar nauwkeurig te kloppen.

Hierbij is sprake van een paradox. Verpleegkundigen dreigen verstrikt te raken in de paradox van "meer handen aan het bed". Een grotere nadruk op "meer handen aan het bed" leidt ertoe dat er niet meer voldoende tijd is om nieuwe kennis en vaardigheden eigen te maken. Immers de tijd die daarvoor nodig is vindt niet of slechts deels aan het bed van de patiënt plaats. En dat leidt tot de neerwaartse spiraal waarbij gebrek aan kennis tot gevolg heeft dat zorgproblemen in onvoldoende mate worden onderkend, wat pijn, ondervoeding, acute verwardheid en doorliggen tot gevolg kan hebben, de patiënt als gevolg hiervan onnodig lijdt en deze extra zorg nodig heeft. 
Om betere en efficiëntere zorg te verlenen is het meten van zorgproblemen als pijn een eerste vereiste. Een te sterke nadruk op de functionele taken van de zorg leidt ertoe dat verpleegkundigen en verzorgenden onvoldoende in staat worden gesteld om hun professionele deskundigheid en verantwoordelijkheid op peil te houden. Vandaar mijn titel van deze oratie: hoe de kwaliteit van de verpleging de kwaliteit van zorg bepaalt.

Dat betekent dat er een constante transfer van wetenschappelijke kennis naar de praktijk van de verpleging nodig is. Daarbij leidt verplegingswetenschappelijk onderzoek tot het ontwikkelen van nieuwe verpleegkundige zorg. Deze verpleegkundige zorg wordt vervolgens in de praktijk toegepast, getoetst en geïmplementeerd. Dit proces wordt ook wel "evidence based nursing" of "evidence based practice" genoemd. "Evidence based nursing" is het proces waarin verpleegkundigen en verzorgenden hun klinische besluiten nemen op grond van de beste onderzoeksresultaten, hun klinische ervaring, de voorkeur van patiënten en de beschikbare hulpmiddelen (Cullum, 2000).

Daarbij wil ik het vijfde punt van zorg noemen. Om een nauwe verwevenheid tussen wetenschap en verpleegkundige praktijk te laten bestaan is het van wezenlijk belang dat onderzoek in sterke mate "experience-based" is en deels wordt gestuurd door problemen uit de praktijk. Het aantal master opgeleide verpleegkundigen dat werkzaam is in de zorg is onvoldoende.

Hoe noodzakelijk is de inzet van master opgeleide verpleegkundigen in de zorg? Dat werd vroeger laatdunkend "academisch billenwassen" genoemd. Heb je een master opleiding nodig om patiënten te kunnen wassen? Nee, dat is beslist niet nodig. Maar de veranderingen in de zorg zijn groot en zonder koplopers en verpleegkundigen die een team naar een nieuwe wijze van zorg verlenen kunnen begeleiden, zal het verpleegkundig handelen in grote mate gebaseerd blijven op traditie en eerdere ervaringen. De verpleging heeft een evenwichtige verdeling van verpleegkundigen nodig van verschillende niveaus. Hoger opgeleide verpleegkundigen en master opgeleide verpleegkundigen dragen bij aan het ontwikkelen van nieuwe innovaties, het verspreiden van nieuwe innovaties, het evalueren van de effecten ervan en het informeren en instrueren van 
verpleegkundigen. In het azM werken een aantal verpleegkundigen enerzijds aan het bed van de patiënt en anderzijds verrichten zij onderzoek. Zij dragen zo in belangrijke mate bij aan nieuwe kennis in de zorg. Dit aantal dient verder te worden uitgebreid. Dus "academisch handelen" is noodzakelijk om vooruitgang in de zorg inhoud te geven.

Het onderzoek dat wordt uitgevoerd richt zich op het onderzoeksmodel waarbij zorgproblemen worden onderzocht in de context, waarbij risicofactoren worden bestudeerd, alsmede de effecten van interventies (Dodd et al., 2001). Hoewel niet alle symptomen adequaat zijn te behandelen, is het van groot belang dat symptomen worden gesignaleerd en behandeld. Er zijn vele voorbeelden hiervan te geven. Ik wil u een aantal voorbeelden geven van onderzoek dat in sterke mate kan bijdragen aan het verbeteren van zorg. Neem de patiënt met een CVA (beroerte). Direct na een beroerte hebben 22 tot $65 \%$ van deze patiënten slikklachten (Daniels et al., 1998; Smithard et al., 1998). Het is van belang dat slikklachten zo vroeg mogelijk worden herkend zodat maatregelen genomen kunnen worden om complicaties te voorkomen. Slikklachten leiden namelijk tot een verhoogd risico op longontsteking en ondervoeding. Dit heeft een langere opname in het ziekenhuis tot gevolg en verhoogde mortaliteit als gevolg van verslikpneumonie (Smithard et al., 1996; Smith Hammanond and Goldstein, 2006).

Het zijn de verpleegkundigen, die in staat zijn om slikklachten te herkennen en maatregelen te treffen. Het is dit onderzoek dat wordt uitgevoerd in het azM en kan bijdragen aan meer inzicht en de behandeling van slikklachten.

Een tweede voorbeeld richt zich op het probleem van acute verwardheid, welke kan optreden bij patiënten in het ziekenhuis. Meestal is deze plotseling ontstane verwardheid het symptoom van een delirium. Naar schatting ontwikkelt 15-53\% van de oudere patiënten postoperatief een delier. Op de Intensive Care komt acute verwardheid veel vaker voor. (Ely et al., 2001; Pisani et al., 2003; Shuster \& Stern, 2002). Maar er bestaat nog geen observatie-instrument voor verpleegkundigen om een delier vast te stellen bij een specifieke groep patiënten op de Intensive Care, namelijk de beademde patiënten. Het niet 
herkennen van een delier kan voor de patiënt ernstige complicaties hebben met een toegenomen kans op sterfte. Patiënten die verward zijn, zijn onrustig en verwijderen hun beademingstube of infuuslijnen. Hoe kan acute verwardheid worden gediagnosticeerd? Wat is de best werkzame behandeling? Hoe kan het dagelijks screenen van delier door verpleegkundigen worden geïmplementeerd? Ook hiervoor geldt dat dit onderzoek wordt uitgevoerd in het azM.

Een derde voorbeeld richt zich op ondervoeding. In een tijd dat de kranten vol staan met berichten dat $40 \%$ van de bevolking met overgewicht heeft te kampen, is $25-40 \%$ van de patiënten in ziekenhuizen en verpleeg- en verzorgingshuizen ondervoed. Onderzoek van Halfens et al. (2006) laat zien dat het terugdringen van ondervoeding moeizaam verloopt. Patiënten met ondervoeding herstellen langzamer en hebben meer complicaties (Kruizenga et al., 2005; Pichard et al., 2004; Stratton et al., 2003). Door het tijdig opsporen van ondervoede patiënten of patiënten met een verhoogd risico op ondervoeding, kan zo snel mogelijk een adequaat voedingsbeleid worden gestart. Naar schatting wordt slechts $50 \%$ van de patiënten met ondervoeding herkend (Kruizenga et al., 2003). Door het gebruik van een eenvoudig screeningsinstrument, gevolgd door een geprotocolleerde voedingsbehandeling stijgt het herkennen van ondervoede patiënten van 50\% naar 80\% (Kruizenga et al., 2005; Baldwin et al. 2007).

Ik heb $\mathrm{u}$ inmiddels vier uiteenlopende voorbeelden gegeven van veelvoorkomende zorgproblemen. Ik kan nog vele andere voorbeelden geven, maar de tijd staat dat niet toe. Hoewel hun fysiologische oorzaak zeer uiteenlopend is, evenals de gevolgen, is er een grote mate van overeenstemming in de systematiek van signaleren, diagnosticeren, verplegen en evalueren. De patiënt is afhankelijk van de verpleegkundige, die als vangnet, als waakhond en als aangever functioneert.

\section{Toekomstig onderzoek}


Daarbij ben ik aangekomen bij het onderzoek in de toekomst. Hoe zal het toekomstige onderzoek eruit zien? Een aantal koerswijzigingen zijn wenselijk. Ten eerste is een verschuiving van het onderzoeksgeld nodig. Veel subsidies richten zich op het implementeren van nieuwe kennis en richtlijnen. Dit heeft tot gevolg dat er minder onderzoeksgelden voor het ontwikkelen van wetenschappelijke kennis beschikbaar is. Hierdoor dreigt de wetenschap ondergeschikt te raken aan het implementeren van nieuwe kennis, wat zelfs leidt tot het implementeren van interventies waarvoor het wetenschappelijke bewijs flinterdun of zelfs afwezig is. Ik wil hier een pleidooi houden voor een meer evenwichtige relatie tussen wetenschappelijke onderzoeksgelden en implementatiesubsidies.

Ten tweede dient in aanvulling op het beschrijven van zorgproblemen een sterkere nadruk te komen op het onderzoeken van de effecten van verpleegkundige handelingen of interventies. Het afgelopen decennium heeft voornamelijk in het teken gestaan van het beschrijven van zorgproblemen. Dit onderzoek heeft in belangrijke mate bijgedragen aan het inzicht in welke mate zorgproblemen voorkomen en wat de gevolgen hiervan voor de patiënt zijn. Maar het is tijd dat naast beschrijvend onderzoek ook effectstudies worden uitgevoerd. Dit betekent een nadrukkelijke verschuiving van descriptieve studies naar effectstudies (Nolan, 2005).

Ten derde zal het accent van de zorg veranderen. De Nederlandse bevolking vergrijst. Over twintig jaar is het aantal 65-plussers in Nederland met de helft toegenomen: van 14\% in 2005 tot 21\% in 2025 (Blokstra et al., 2007). Door de groei en de vergrijzing zal het aantal chronische zieken in de komende 20 jaar enorm toenemen. Vooral het aantal diabeten en mensen met botontkalking (osteoporose) zal stijgen. Maar ook astma/COPD en chronische hartziekten zullen sterk stijgen. Hoewel er een sterke tendens is gericht op meer medisch technisch handelen ("high tech"), is het mijn stellige overtuiging dat het accent van de zorg dient te verschuiven van "high tech" naar "high care". Daartoe dient de basiszorg te worden versterkt. 
Ten vierde zal het onderzoek zich meer gaan richten op de groeiende groep ouderen, waar nu nog weinig onderzoek naar wordt verricht. Pijn kan op eenvoudige wijze worden gemeten bij patiënten die zich kunnen uiten. Maar hoe meet je pijn bij ouderen die zich niet meer kunnen uiten, bijvoorbeeld als gevolg van Alzheimer? Hoe evalueer je het effect van een pijnbehandeling bij een patiënt met vasculaire dementie? Welke meetinstrumenten zijn geschikt om door verpleegkundigen gebruikt te worden? Hoe implementeer je deze meetinstrumenten in de verpleegkundige praktijk? Door onderzoekers Van Herk en Boerlage vanuit het Erasmus MC in Rotterdam en Zwakhalen van de vakgroep Verpleging en Verzorging wordt onderzoek naar pijn bij ouderen en pijn bij ouderen met uitingsbeperkingen verricht (Boerlage et al., 2007; van Herk et al., 2007; Zwakhalen et al., 2007).

Ten vijfde zal de groeiende groep ouderen tot gevolg hebben dat ziekenhuiszorg in de toekomst voor een kleinere groep patiënten beschikbaar zal zijn. De grootste groep met een of meerdere aandoeningen of chronische ziekten zal in de toekomst steeds meer thuis verblijven. Deze patiënten hebben met een groot aantal hulpverleners van doen, waarbij de verpleegkundige een steeds meer coördinerende rol zal gaan vervullen en waarbij substitutie van zorg zal plaatsvinden.

Tot slot, zal betere en efficiëntere zorg met behulp van "telemonitoring" en "telemedicine" een steeds grote vlucht nemen. Een voorbeeld hiervan is het project "telebegeleiding bij patiënten met chronisch hartfalen", waarbij mensen in de thuissituatie dagelijks hun klachten, kennis en gedrag rapporteren aan het ziekenhuis, zonder dat daarvoor direct contact met een zorgverlener nodig is. Door patiënten op afstand te monitoren en begeleiden kunnen problemen sneller worden gesignaleerd en behandeld, kan de behandeling vaker buiten het ziekenhuis plaatsvinden, worden patiënten beter geïnformeerd en blijven patiënten langer zelfstandig. Daardoor kan het ziekenhuis efficiënter werken (Vrijhoef et al., 2005). Niet alleen kunnen symptomen van patiënten op afstand goed worden gevolgd zonder directe tussenkomst van een hulpverlener, ook kan het gebruik van medicijnen door patiënten in de thuissituatie worden bijgehouden. 
Intelligente pillenpotten houden bij of en hoe patiënten hun medicatie innemen en verpleegkundigen kunnen op maat informatie en instructie geven aan patiënten, zodat de klachten zo lang mogelijk onder controle blijven (Oldenmenger et al., 2007).

\section{Onderwijs}

Hierbij ben ik aangekomen bij de andere belangrijke kernactiviteit van mijn functie, namelijk onderwijs. Onderwijs is essentieel om de kwaliteit van zorg te verbeteren. De onderwijsactiviteiten van de vakgroep richten zich zowel op bachelorstudenten, master studenten, als onderwijs voor promovendi. De vakgroep Verpleging en Verzorging draagt binnen het bacheloronderwijs bij aan de bachelor Algemene Gezondheidswetenschappen (AGW), de bachelor European Public Health (EPH), de master Health Services Innovation (HSI), Health Policy, Economics and Management (HPEM) en de Health Science Research master.

In de afgelopen 25 jaar hebben ongeveer 1700 Nederlandse verpleegkundigen een master opleiding gevolgd. Het merendeel daarvan is opgeleid door de Universiteit Maastricht. Toch is dit aantal gering in vergelijking tot de totale groep verpleegkundigen $(0,7 \%)$. Andere Europese lidstaten laten zien dat in 50\% $(\mathrm{N}=40)$ van de Europese landen verplegingswetenschap op master niveau wordt aangeboden (Dalderup, 2006; Spitzer et al., 2006). Gemiddeld heeft $0.8 \%$ van de verpleegkundigen een master opleiding behaald. In de Verenigde Staten is $9.6 \%$ van de verpleegkundigen op master niveau opgeleid (American Association of Colleges of Nursing, 2005).

Daarmee uit ik mijn zesde punt van zorg. Het opleidingsniveau van verpleegkundigen op master niveau blijt in sterke mate achter vergeleken met de totale verpleegkundige beroepsgroep, zowel in Nederland als in de andere Europese landen. Het is dan ook van groot belang om in de komende jaren tot uitbreiding te komen van het aantal master opgeleide verpleegkundigen. 
Verplegingswetenschap bestaat in Nederland ruim 25 jaar. Na de start van de opleiding aan de universiteit Maastricht in 1980, is het behalen van een wetenschappelijke master opleiding voor verpleegkundigen slechts mogelijk in Utrecht, naast de master Health Care studies en de recent gestarte master opleiding Health Services Innovation in Maastricht.

De universiteit Maastricht heeft hierin altijd een voortrekkersrol vervult en zal dit blijven doen door de intentie om binnen korte tijd een Master Nursing Science te starten die toegankelijk is voor verpleegkundigen uit andere Europese landen.

\section{Tot slot}

Ik heb een aantal zaken voor het voetlicht gebracht en ik heb u laten zien hoe belangrijk het werk van verpleegkundigen en verzorgenden is. Tegelijkertijd heb ik getracht $u$ inzicht te geven in de prominente bijdrage die verpleegkundigen leveren aan de totale zorg. Ik heb beargumenteerd dat de kwaliteit van de verpleging de kwaliteit van zorg bepaalt. Ik heb nadrukkelijk een pleidooi gehouden voor een accentverschuiving in de zorg, waarbij zowel in het onderwijs, als in het onderzoek, maar ook in de patiëntenzorg meer aandacht dient te komen voor de belangrijke bijdragen die verpleegkundigen leveren aan de kwaliteit van zorg.

\section{Dankwoord}

Graag wil ik mijn rede besluiten met een dankwoord. Mijn dank gaat uit naar allen die aan de totstandkoming van mijn benoeming hebben bijgedragen. Ik wil graag een aantal personen bij naam noemen Het College van Bestuur van de Universiteit Maastricht, het bestuur van de Faculty of Health, Medicine and Life Sciences en de Raad van Bestuur van het academisch ziekenhuis Maastricht (azM) dank ik voor het in mij gestelde vertrouwen. Twee personen wil ik daarbij met naam noemen, te weten 
hooggeleerde Prof. dr. Frits van Merode, decaan en drs. Guy Peeters, voorzitter van de Raad van Bestuur van het academisch ziekenhuis Maastricht (azM). Het is dankzij de combinatie die mij is geboden om mijn functie van hoogleraar verplegingswetenschap uit te oefenen in het ziekenhuis en aan de universiteit, die de invulling ervan zo wezenlijk maakt. Met de instelling van een leerstoel op het terrein van de Verplegingswetenschap is en blijft de Universiteit Maastricht een voorloper. Ik doe mijn uiterste best de verwachtingen waar te maken. Als voorzitter van de vakgroep Verpleging en Verzorging dank ik de meer dan 40 medewerkers voor hun vertrouwen en enthousiasme waarop men vaak door jarenlange arbeid bijdraagt aan de verpleegkundige zorg en de hechte groep die wij met elkaar vormen. Ik dank hooggeleerde Prof. Dr. Ruud Kempen en hooggeleerde Prof. Dr. Jan Hamers dat zij deel uitmaken van de vakgroep Verpleging en Verzorging en vorm geven aan het onderzoeksprogramma zorg voor ouderen en zeergeleerde Dr. Bert Vrijhoef voor zijn inzet voor het onderwijs en het onderzoeksprogramma zorg voor chronisch zieken.

De stafgroep verpleging van het stafdirectoraat Zorg en Leren, Monique Hanraets, Barbara Solberg, Thijs Spreuwenbeg, Theo Vanspauwen en Gerard Castermans bedank ik voor hun tomeloze en creatieve inzet om die veranderingen in de zorg in het azM te realiseren. Hooggeleerde Prof. Dr. Karel Leunissen dank ik als directeur van het stafdirectoraat Zorg en Leren voor zijn brede visie op kwaliteit.

De directeur van onderzoeksinstituut CAPHRI, hooggeleerde Prof. Dr. Guy Widdershoven, dank ik voor de mogelijkheid om onderzoek uit te voeren. Hier in Maastricht heb ik mijn opleiding gevolgd en veel geleerd van onder andere hooggeleerde Prof. Dr. Hans Philipsen. Na mijn opleiding gezondheidswetenschappen hebben vele anderen bijgedragen aan mijn verdere ontwikkeling. Twee van hen wil ik uitdrukkelijk noemen: hooggeleerde Prof. Dr. Frits van Dam van het Nederlands Kanker Instituut/Antoni van Leeuwenhoek ziekenhuis en Universiteit van Amsterdam en hooggeleerde Prof. Dr. Jan Passchier van het Erasmus MC. 
Mijn dank gaat uit naar de promovendi en onderzoekers die ik op dit moment begeleid. Jeroen Hendriks, Nelleke de Wit, Josiane Boyne, Jessie Lemmens, Esther Meesterberends en de onderzoekers van het Erasmus MC Rhodee van Herk, Annemerle Beerthuizen, Wendy Oldenmenger, Anneke Boerlage en Tilly Baan dank ik voor de enorme inzet bij het onderzoek. Zij zijn het die tot nieuwe inzichten komen.

Een speciaal woord van dank gaat uit naar collega's in de ondersteunende functies. Het valt niet mee om iemand die meerder keren per dag tussen de universiteit en het ziekenhuis pendelt onder controle te houden. Julie Rosier en Willy-Anne Kanters, alsmede Masha Wakker en Ria Erven ben ik dank verschuldigd.

Tot slot, een speciaal woord van dank aan mijn lieve familie en vrienden. Ik vind het een groot voorrecht dat mijn beide ouders, die in grote mate hebben bijgedragen aan de persoon die ik nu ben, hierbij aanwezig kunnen zijn. Ook mijn lieve dochter Novia verdient speciale aandacht. Ze is nog te klein om hier aanwezig te zijn, laat staan dat ze er iets van kan begrijpen. Waarschijnlijk zou ze me in deze kleding niet eens herkennen. Eerst hoogleraar worden en daarna moeder is een niet alledaagse combinatie. Maar zo wordt het bewijs geleverd dat carrière en kinderen samen kunnen gaan. Ook al heeft zij voor enige vertraging van deze oratie gezorgd, het geluk dat ze brengt is immens groot. Lieve Naomi en Olivia, jullie zijn sinds 5 jaar mijn allerliefste (nep)kinderen. Jullie vragen je wel eens af waarom er nooit een universiteit in Velp is gebouwd. Ik heb daar nooit een goed antwoord op kunnen geven, want dat zou de doordeweekse afstand tussen ons zoveel kleiner maken.

Tot slot, liefste Bernard, jij en ik hadden niet kunnen vermoeden dat we in een "rollercoaster" van veranderingen terecht zouden komen: ander werk, ander huis, andere locatie en een ander kind. Je stond niet altijd direct te juichen, maar inmiddels ben je meer Limburger dan ik. Ik wil je bedanken voor je lef en flexibiliteit om met mij die stap naar het verre zuiden te wagen. Want uitkijken over de Limburgse heuvels is met jou oneindig veel leuker dan zonder jou. 
Dames en heren,

Ik heb gezegd.

\section{Referenties}

Aiken, L.H., Clarke, S.P., Sloane, D.M., Sochalski, J., \& Silber, J.H. (2002). Hospital nurse staffing and patient mortality, nurse burnout, and job dissatifaction. Journal of American Medical Association; 288, 1987-1993.

Aiken, L.H., Clarke, S.P., \& Sloane, D.M. (2002). Hospital staffing, organizational support, and quality of care: cross-national findings. International Journal for Quality in Health Care; 14, 5-13.

Aiken, L.H., Clarke, S.P., Silber, J.H., \& Sloane, D. (2003). "Hospital nurse staffing, education, and patient mortality". LDI Issue Brief; 9(2), 1-4.

American Association of Colleges of Nursing. (2005). Nursing fact sheet. Opgehaald op 25 juli 2007 van: www.aacn.nche.edu.

Balas, E.A., \& Boren, S.A. (2000). Managing clinical knowledge for health care improvement. In J. Bemmel \& A.T. McCray (eds.). Yearbook of medical informatics, Stuttgart: Schattauer, pp. 65-70.

Baldwin, C., Parsons, T., \& Logan, S. (2007). Dietary advice for illnessrelated malnutrition in adults. Cochrane Database Systematic Reviews; 24(1), CD002008.

Blokstra, A., Baan, C.A., Boshuizen, H.C., Feenstra, T.L., Hoogenveen, R.T., Picavet, H.S.J., Smit, H.A., Wijga, A.H., \& Verschuren, W.M.M. (2007). Vergrijzing en toekomstige ziektelast: prognose chronische ziektenprevalentie 2005-2025. RIVM rapport 260401004. Bilthoven: RIVM.

Bloomfield, S.A. (1997). Changes in musculoskeletal structure and function with prolonged bed rest. Medicine and Science in Sports and Exercise; 29(2), 197-206.

Boerlage, A., Stronks, D.L., Van Dijk, M., Baar, F.P.M., Van der Rijt, C.C.D., \& De Wit, R. (2007). Pijnregistratie en pijnbehandeling in verpleeghuizen kunnen nog beter. Verpleegkunde; 22, 98-105. 
Canadian Association of Schools of Nursing/Association Canadienne des Écoles des Sciences Infirmières (2004). Draft position statement on Doctoral Education in Nursing in Canada.

Carter, S., \& Giannoudis, P.V. (2006). Evolution of peri-operative care of patients (editorial). Injury: International Journal of Care of the Injured; 37(S), S1.

Clarke SP, Sloane DM, Aiken LH. Effects of hospital staffing and organizational climate on needlestick injuries to nurses. American Journal of Public Health; 92, 1115-1159.

Cullum, N., DiCenso, A., Ciliska, D. (1997). Evidence-based nursing: an introduction. Nursing Standard; 11, 32-33.

Dalderup, J.E.M. (2006). Verpleegkundige opleidingen op uitvoerend beroepsniveau, master niveau en doctor niveau in Europa: een beschrijvend onderzoek naar de cijfers aangaande verplegingswetenschappelijke opleidingen in Europa. Jaarwerkstuk Universiteit Maastricht. Maastricht: Universiteit Maastricht: Zorgwetenschappen.

Daniels, S.K., Brailey, K., Priestly, D.H., Herrington, L.R., Weisberg, L.A., \& Foundas, A.L. (1998). Aspiration in patients with acute stroke. Archives of Physical Medicine and Rehabilitation; 79, 14-19.

De Rond, M., De Wit, R., Van Dam, F., Van Campen, B., Den Hartog, Y., Klievink, R., Nieweg, R., Noort, J., Wagenaar, M., \& Van Campen, B. (1999). Daily pain assessment: value for nurses and patients. Journal of Advanced Nursing; 29, 436-444.

De Rond, M., De Wit, R., \& Van Dam, F. (2001). The implementation of a Pain Monitoring Programme for nurses in daily clinical practice: results of a follow-up study in five hospitals. Journal of Advanced Nursing; 35, 590-598.

De Veer, A.J.E., Poortvliet, E., Vogel, B., Francke, A.L. (2007). De aantrekkelijkheid van het beroep 2007. Een peiling onder het Panel Verpleegkundigen en Verzorgenden. Utrecht: LEVVINIVEL. 
Dodd, M., Janson, S., Facione, N., Faucett, J., Froelicherm, E.S., Humphreys, J., et al. (2001). Advancing the science of symptom management. Journal of Advanced Nursing; 33, 668-676.

Estabrooks, C.A., Midodzi, W.K,, Cummings, G.G., Ricker, K., Giovannetti, (2005). The impact of hospital nursing characteristics on 30-day mortality. Nursing Research; 54, 74-84.

Ely, E.W., Margolin, R., Francis, J., May, L., Truman, B., Dittus, R., et al. (2001). Evaluation of delirium in critically ill patients : validation of the Confusion Assessment Method for the Intensive Care Unit (CAM-ICU). Critical Care Medicine; 29, 1370-1379.

Gogia, P., Schneider, V.S., Leblanc, A.D., Krebs, J., Kasson, C., \& Pientok, C. (1988). Bed rest effect on extremity muscle torque in healthy men. Archives of Physical Medicine and Rehabilitation; 69, 1030-1032.

Halfens, R.J.G., Janssen, M.A.P., Meijers, J.M.M., \& Wansink, S.W. (2006). Landelijke Prevalentiemeting Zorgproblemen: resultaten negende jaarlijkse meting 2006. Maastricht: Universiteit Maastricht.

IGZ Inspectie voor de Gezondheidszorg, NVZ Vereniging van ziekenhuizen, NFU Nederlandse Federatie van Universitair Medische Centra, \& OMS Orde van Medisch Specialisten (2006a). De basisset prestatie-indicatoren ziekenhuizen 2007. Utrecht. Opgehaald op 20 september 2007 van: www.igz.nl

IGZ Inspectie voor de Gezondheidszorg (2006b). Het resultaat telt 2005: prestatie-indicatoren als onafhankelijke graadmeter voor de kwaliteit van in ziekenhuizen verleende zorg. Opgehaald op 20 september 2007 van: http://www.igz.nl/15451/17873/Rapport 2005-05 Het resulta1.pdf

International Council of Nurses. (2006). The ICN code of ethics for nurses. Geneva: ICN. Opgehaald van: http://www.icn.ch/icncode.pdf.

Karanikolas, M., \& Swarm, R.A. (2000). Current trends in perioperative pain management. Anesthesiology Clinics of North America; 18, 575-599.

Keet, J.G.M. (1987). Kosten-batenanalyse van de totale heupprothese. Nederlands Tijdschrift voor Geneeskunde; 131, 1965-1969. 
Kehlet, H. (1999). Acute pain control and accelerated postoperative recovery. Surgical Clinics of North America; 79, 431-443.

Kehlet, H. (2004). Effect of postoperative pain treatment on outcome: current status and future strategies. Langenbeck's Archives of Surgery; 389, 244-249.

Kruizenga, H.M, Van Tulder, M.W., Seidell, J.C., Thijs, A., Ader, H.J. \& Van Bokhorst-de van der Schueren, M.A.E. (2005). Effectiveness and costeffectiveness of early screening and treatment of malnourished patients. American Journal of Clinical Nutrition; 82, 1082-1089.

Kruizenga, H.M., Wierdsma, N.J., Van Bokhorst-de van der Schueren, M.A.E., Hollander, H.J., Jonkers-Schuitema, C.F., Van der Heijden, E., et al. (2003). Screening of nutritional status in The Netherlands. Clinical Nutrition; 22(2), 147-152.

LEVV Landelijk Expertisecentrum Verpleging \& Verzorging. (2006a). Factsheet Het aantal werkzame personen per branche. Utrecht: LEVV.

LEVV Landelijk Expertisecentrum Verpleging \& Verzorging. (2006b). Factsheet Het aantal BIG-geregistreerde verpleegkundigen naar leeftijd en geslacht in 2006. Utrecht: LEVV.

Needleman, J., Buerhaus, P., Maattke, S., Stewart, M., \& Zelevinsky, K. (2002). Nurse-staffing levels and the quality of care in hospitals. New England Journal of Medicine; 346, 1715-1722.

Nolan, M.R. (2005). Reconciling tensions between research, evidencebased practice and user participation: time for nursing to take the lead. International Journal of Nursing studies; 42, 503-505.

Oldenmenger, W.H., Echteld, M.A., De Wit, R., Stronks, D.L., Sillevis Smitt, P.A.E., Stoter, G., \& Van der Rijt, C.C.D. (2007). Analgesic adherence measurement in cancer patients: comparison between electronic monitoring and diary. Journal of Pain and Symptom Management; doi:10.1016/j.jpainsymman.2007.01.015

Pichard, C., Kyle, U.G., Morabia, A., Perrier, A., Vermeulen, B., \& Unger, P. (2004). Nutritional assessment: lean body mass depletion at hospital admission 
is associated with an increased length of stay. American Journal of Clinical Nutrition; 79, 613-618.

Pisani, M.A., McNicoll, L., \& Inouye, S.K. (2003). Cognitive impairment in the intensive care unit. Clinics in Chest Medicine; 24, 727-737.

Prismant. (2007). Gegevens Landelijke Medische Registratie (LMR). Gegevens ontvangen op 14 november 2007.

Rafferty, A.M., Clarke, S.P., Coles, J., Ball, J., James, P., McKee, M., \& Aitken, L.H. (2007). Outcomes of variation in hospital nurse staffing in English hospitals: cross-sectional analysis of survey data and discharge records. International Journal of Nursing Studies; 44, 175-182.

Shuster, J.L., \& Stern, T. (2002). Intensive care units. In M.G. Wise, \& J.R. Rundell (red.), Textbook of consultation-liaison psychiatry. 2nd ed. New York: American Psychiatric Press, pp. 753-771.

Siu, A.L., Penrod, J.D., Boockvar, K.S., Koval, K., Strauss, E., \& Morrison, R.S. (2006). Early ambulation after hip fracture: effects on function and mortality. Archives of Internal Medicine; 166, 766-771.

Smith Hammond, C.A., \& Goldstein, L.B. (2006). Cough and aspiration of food and liquids due to oral-pharyngeal dysphagia : ACCP evidence-based clinical practice guidelines. Chest; 129(1, supplement), 154S-168S.

Smithard, D.G., O'Neill, P.A., Park, C., England, R., Renwick, D.S., Wyatt, R., et al. (1998). Can bedside assessment reliably exclude aspiration following acute stroke? Age and Ageing; 27, 99-106.

Smithard, D.G., O'Neill, P.A., Park, C., Morris, J., Wyatt, R., England, R., et al. (1996). Complications and outcome after acute stroke : does dysphagia matter? Stroke; 27, 1200-1204.

Spitzer, A., \& Perrenoud, B. (2006). Reforms in nursing education across Western Europe: implementation process and current status. Journal of Professional Nursing; 22, 162-171.

Stevens, F., \& Philipsen, H. (2003). In C.W. Aakster \& J.W. Groothof, Medische sociologie. Groningen; Houten: Wolters-Noordhoff. 
Stratton, R.J., Green, C.J., \& Elia, M. (2003). Consequences of disease related malnutrition. In R.J. Stratton, C.J. Green, \& M. Elia (eds.). Disease related malnutrition. Cambridge, MA: CABI, pp.113-155.

Stukart, M.J., Strijbosch, M.P.W., Hooiveld, M.H.W., Van Rees-Wortelboer, M.M., Vandenbroucke, J.P., \& Klasen, E.C. (2006). Artsen en wetenschappelijk onderzoek: lichte teruggang van het aantal gepromoveerde artsen. Nederlands Tijdschrift voor Geneeskunde; 150, 1509-1512.

Van de Haterd, J., Liefhebber, S., Luijkx, J., Mast, J., \& Van Dam, C. (2005). NIZW beroepsontwikkelingen en NIZW zorg: beroepscompetentieprofiel mboverpleegkundige. Utrecht: NIZW.

Van Herk, R., Van Dijk, M., Baar, F.P.M., Tibboel, D., \& De Wit, R. (2007). Observation scales for pain assessment in older adults with cognitive impairments. Nursing Research; 56(1), 34-43.

V\&VN Verpleegkundigen \& Verzorgenden Nederland (2007). Goede raad is goud waard: resultaten V\&VN VAR-enquête 2006. Utrecht: V\&VN.

Vrijhoef, H.J.M., Janssen-Boyne, J.J.J., Engering, G., \& Gorgels, A.P.M. (2005). Telebegeleiding bij hartfalen: haalbaarheidsonderzoek van de Health Buddy ${ }^{\circledR}$. Maastricht: Universiteit Maastricht; Academisch Ziekenhuis Maastricht.

Watt-Watson, J., Stevens, B., Garfinkel, P., Streiner, D., \& Gallop, R. (2001). Relationship between nurses' pain knowledge and pain management outcomes for their postoperative cardiac patients. Journal of Advances Nursing, 36, 535545.

Zwakhalen, S.M., Hamers, J.P., \& Berger, M.P. (2007). Improving the clinical usefulness of a behavioural pain scale for older people with dementia. Journal of Advanced Nursing; 58, 493-502. 